\title{
PEMBINAAN CIVIC DISPOSITION MELALUI MODEL PEMBELAJARAN PROJECT CITIZEN DALAM MATA KULIAH PKn 2 UNTUK MENUMBUHKAN NILAI MORAL MAHASISWA
}

\author{
Beny Dwi Lukitoaji \\ beny@upy.ac.id \\ Universitas PGRI Yogyakarta
}

\begin{abstract}
This study aims to determine the guidance of civic disposition through the model project of citizen learning in the course of Civics 2 to foster the moral value of the students of PGSD FKIP UPY. The research design using qualitative approach and the method used is case study. Participants in this study were two semester students in the course of PKn 2 on PGSD FKIP UPY Prodi. Data collection techniques used observation, interviews, documentation. Testing the validity of data by means of extension of observation and triangulation. Processing techniques and data analysis using interactive process cycle analysis consisting of data reduction, data presentation, and data verification. The result of the research is that there are several civic dispositions that appear in the learning of Civics 2 course with the project model of citizen learning, among others: responsibility, discipline, respect for human dignity, caring, politeness, critical thinking, listening, negotiating and competence, the common good, participate in problems together in an open way, develop self-confidence.
\end{abstract}

Keywords: citizen project learning model, civic disposition, moral values

\begin{abstract}
ABSTRAK
Penelitian ini bertujuan untuk mengetahui pembinaan civic disposition melalui model pembelajaran project citizen dalam mata kuliah PKn 2 untuk menumbuhkan nilai moral mahasiswa prodi PGSD FKIP UPY. Desain penelitian menggunakan pendekatan kualitatif dan metode yang digunakan adalah studi kasus. Partisipan dalam penelitian ini adalah mahasiswa semester dua pada mata kuliah PKn 2 pada prodi PGSD FKIP UPY. Teknik pengumpulan data menggunakan observasi, wawancara, dokumentasi. Pengujian keabsahan data dengan cara perpanjangan pengamatan dan triangulasi. Teknik pengolahan dan analisis data menggunakan analisis proses siklus yang interaktif yang terdiri dari reduksi data, penyajian data, dan verifikasi data. Hasil penelitian adalah terdapat beberapa civic disposition yang muncul dalam pembelajaran mata kuliah PKn 2 dengan model pembelajaran project citizen antara lain: tanggung jawab, disiplin, penghargaan terhadap harkat dan martabat manusia, kepedulian, kesopanan, berpikir kritis, kemauan mendengar, bernegosiasi dan berkompetensi, memajukan kebaikan umum, berpartisipasi dalam masalah bersama dengan cara yang terbuka, mengembangkan kepercayaan diri.
\end{abstract}

Kata kunci : model pembelajaran project citizen, civic disposition, nilai moral 
JURNAL MORAL KEMASYARAKATAN - VOL.2, NO.2, DESEMBER 2017 PEMBINAAN CIVIC DISPOSITION MELALUI MODEL PEMBELAJARAN PROJECT CITIZEN

\section{PENDAHULUAN}

Penelitian ini didasari dengan adanya keresahan dari peneliti sendiri dengan adanya perubahan nilai-nilai positif dalam lingkungan pendidikan, sebagai contoh banyak terjadinya kekerasan oleh guru terhadap siswa, pelecehan seksual oleh guru terhadap siswa, tawuran antar pelajar bahkan mahasiswa, narkoba dan seks bebas dikalangan pelajar dan mahasiswa serta berbagai kenakalan dan perilaku menyimpang dari para generasi muda bangsa kita. Sementara itu menurut penelitian Indra Wirdhana ketua Badan Kependudukan dan Keluarga Berencana Nasional (BkkbN), mengemukakan bahwa kasus aborsi dikalangan remaja, diperoleh data 2,5 juta jiwa perempuan pernah melakukan aborsi dan dari jumlah ini 27 persen atau 700 ribu dilakukan oleh remaja. Untuk Narkoba menunjukkan 1,5\% dari jumlah penduduk Indonesia atau 3,2 juta jiwa pengguna narkoba dan dari jumlah itu $78 \%$ dari kalangan remaja. Sedang kasus AIDS hingga Desember 2009 sebesar 19.973 kasus dan dari jumlah ini 50,3\% ditularkan melalui hubungan heteroseksual (http://health.liputan6.com).

Perkelahian termasuk jenis kenakalan remaja akibat kompleksinya kehidupan kota yang disebabkan karena masalah sepele. Tawuran pelajar sekolah menjadi potret buram dalam dunia pendidikan Indonesia. Pada 2010, setidaknya terjadi 128 kasus tawuran antar pelajar. Angka itu melonjak tajam lebih dari 100 persen pada 2011, yakni 330 kasus tawuran yang menewaskan 82 pelajar. Pada Januari-Juni 2012, telah terjadi 139 tawuran yang menewaskan 12 pelajar. Fenomena kasus seks di luar nikah di Indonesia menurut Direktur Bina Kesehatan Anak Kementerian Kesehatan Republik Indonesia, dr. Elizabeth Jane Soepardi mengalami peningkatan walaupun peningkatannya sedikit namun jumlahnya terbilang banyak yaitu sebanyak 14,6 persen pada pria dan 4,5 persen pada perempuan (http://beritasore.com). Penyalahgunaan narkoba di Indonesia sudah sampai ke tingkat yang sangat mengkhawatirkan, fakta di lapangan menunjukkan bahwa 50\% penghuni LAPAS (Lembaga Pemasyarakatan) disebabkan oleh kasus narkoba. Berita kriminal di media massa, baik media cetak maupun elektronik dipenuhi oleh berita tentang penyalahgunaan narkoba. Korban narkoba meluas ke semua lapisan masyarakat dari pelajar, mahasiswa, artis, ibu rumah tangga, pedagang, supir angkot, anak jalanan, pekerja, dan lain sebagainya. Narkoba dengan mudahnya diperoleh, bahkan dapat diracik sendiri yang sulit dideteksi, pabrik narkoba secara ilegalpun sudah didapati di Indonesia (Eleanora, 2011). 
JURNAL MORAL KEMASYARAKATAN - VOL.2, NO.2, DESEMBER 2017 PEMBINAAN CIVIC DISPOSITION MELALUI MODEL PEMBELAJARAN PROJECT CITIZEN

Wening (2012) juga mengemukakan permasalahan yang dihadapi oleh bangsa terkait dengan permasalahan kemampuan sosial sangat mengemuka manakala perilaku materialisme yang menganggap bahwa seolah-olah materi, benda, dan uang adalah segala-galanya. Perilaku materialistik ini dapat mengancam terkikisnya nilai-nilai kehidupan manusia, misalnya nilai keimanan, kejujuran, ketertiban, kendali diri, pengorbanan, tanggung jawab, dan kebersamaan. Fenomena perilaku materialistik ini dapat meruntuhkan nilai-nilai kesantunan, tepat waktu, amanah, empati, hormat pada perbedaan pendapat, dan hormat pada orang lain. Perilaku konsumtif merupakan suatu fenomena psikoekonomik yang banyak melanda kehidupan masyarakat, terutama yang tinggal di perkotaan. Fenomena ini menarik untuk diteliti mengingat perilaku konsumtif juga banyak melanda kehidupan remaja di kota-kota besar, yang sebenarnya belum memiliki kemampuan finansial untuk memenuhi kebutuhannya.

Upaya untuk mengatasi permasalahan tersebut dilakukan dengan cara membina dimensidimensi kompetensi kewarganegaraan (civic competence) mahasiswa agar memiliki karakter yang kuat. Pembinaan civic competence dapat dilakukan melalui pendidikan dengan proses pembelajaran yang bermakna. Untuk menjadi warga negara yang baik dan cerdas (to be smart and good citizen) maka ketiga kompetensi tersebut harus berjalan seimbang dan beriringan. Jadi dapat disimpulkan pembinaan civic competence dapat dibina melalui proses pembelajaran salah satunya dengan ketepatan pemilihan model pembelajaran. Mayoritas pembelajaran saat ini hanya menekankan pada civic knowledge atau hanya mementingkan pengetahuan kewarganegaraan, sedangkan civic skill dan civic disposition belum mendapat perhatian yang sama. Oleh karena itu dengan model pembelajaran project citizen dapat melatih dan membina civic knowledge, civic skill, civic disposition dari mahasiswa. Menurut Center for Civic Education (CCE) 1998 yang dikutip oleh Budimansyah (2012:69) mengemukakan bahwa titik berat dari paket pembelajaran project citizen adalah perlibatan peserta didik dalam keseluruhan proses, dan dengan proses itu peserta didik difasilitasi untuk mendapatkan pengetahuan, sikap, dan keterampilan. Untuk itu penelitian tentang pembinaan civic disposition melalui model pembelajaran project citizen dalam mata kuliah PKn 2 untuk mengembangkan nilai moral mahasiswa menjadi hal yang sangat penting untuk dilakukan guna merancang solusi yang tepat bagi permasalahan karakter generasi muda bangsa Indonesia terutama mempersiapkan kompetensi warga negara. 


\section{METODE}

Desain penelitian yang digunakan adalah dengan pendekatan kualitatif dan metode yang digunakan dalam penelitian ini adalah studi kasus. Partisipan dalam penelitian ini adalah mahasiswa semester dua yang terdaftar di mata kuliah Pendidikan Kewarganegaraan 2 pada Program Studi Pendidikan Guru Sekolah Dasar Fakultas Keguruan dan Ilmu Pendidikan Universitas PGRI Yogyakarta. Teknik pengumpulan data dalam penelitian ini dengan menggunakan observasi, wawancara, dokumentasi. Pengujian keabsahan data penulisan dilakukan dengan cara perpanjangan pengamatan dan triangulasi. Teknik pengolahan dan analisis data menggunakan analisis proses siklus yang interaktif yang terdiri dari reduksi data, penyajian data, dan verifikasi data.

\section{HASIL DAN PEMBAHASAN}

\section{Hasil}

Pembinaan Civic Disposition melalui Model Pembelajaran Project Citizen dalam mata kuliah Pendidikan Kewarganegaraan 2 untuk menumbuhkan nilai moral mahasiswa.

Pendidikan Kewarganegaraan 2 merupakan mata kuliah wajib dengan bobot 3 sks yang harus ditempuh oleh mahasiswa prodi PGSD. Materi yang dibahas dalam mata kuliah PKn 2 adalah materi yang berhubungan dengan Pendidikan Kewarganegaraan Sekolah Dasar sehingga hal ini menunjukkan bahwa mata kuliah ini membekali mahasiswa dalam bidang keilmuan yang akan digunakan kelak saat menjadi guru SD. Kompetensi mata kuliah PKn 2 adalah mahasiswa mampu menguasai dan mengembangkan materi pembelajaran Pendidikan Kewarganegaraan serta menerapkan pada proses pembelajaran di sekolah dasar. Deskripsi mata kuliah Pendidikan Kewarganegaraan 2 sebagai berikut mata kuliah ini bertujuan untuk memberikan perspektif mendasar dan dinamika terkini tentang hak-hak dan kewajiban warga negara khususnya yang berkaitan dengan semakin diterimanya Hak Asasi Manusia (HAM) dalam praktik penyelenggaraan kehidupan berbangsa dan bernegara. Mata kuliah ini difokuskan pada pemahaman komprehensif terhadap nilai-nilai dan norma-norma kewarganegaraan, hak asasi manusia, dan hubungan antar warga negara, wawasan nusantara, dan usaha-usaha menjaga keutuhan NKRI. Soft skill yang dikembangkan dalam mata kuliah Pendidikan Kewarganegaraan 2 adalah kerjasama, kreatifitas, tanggung jawab, berpikir kritis dan inovatif. Berdasarkan 
JURNAL MORAL KEMASYARAKATAN - VOL.2, NO.2, DESEMBER 2017 PEMBINAAN CIVIC DISPOSITION MELALUI MODEL PEMBELAJARAN PROJECT CITIZEN

gambaran dari mata kuliah Pendidikan Kewarganegaraan 2 tersebut dapat dilihat untuk aspek penekanan kepada mahasiswa terdiri dari pengetahuan (knowledge), keterampilan (skill), karakter (disposition). Akan tetapi yang menjadi fokus dalam penelitian ini adalah aspek civic disposition atau biasanya disebut dengan karakter kewarganegaraan.

Civic disposition dapat dibina melalui model pembelajaran project citizen. Berikut langkahlangkah model pembelajaran project citizen yang dikemukakan oleh Budimansyah (2012: 77 119) sebagai berikut: (1) mengidentifikasi masalah, (2) memilih masalah untuk bahan kajian kelas, (3) mengumpulkan informasi, (4) mengembangkan portofolio kelas, (5) menyajikan portofolio, (6) merefleksi pengalaman belajar. Penelitian ini menghasilkan temuan yang didasarkan terhadap kriteria civic disposition yang dikemukakan oleh Winataputra (2001: 388420) dan Winarno (2013: 179) sebagai berikut:

Langkah 1. Mengidentifikasi masalah

Di dalam langkah pertama ada beberapa kriteria civic dispositon yang muncul antara lain, (1) mahasiswa dilatih untuk tanggung jawab terhadap tugas yang diberikan berupa ikut aktif mengidentifikasi masalah dari berbagai sumber, (2) penghargaan terhadap harkat dan martabat manusia, (3) mahasiswa menjadi pribadi yang mau menerima saran dan masukan dari teman sebaya, (4) mahasiswa dalam kelas menunjukkan sikap yang demokratis, (5) memajukan kebaikan umum dengan sudah peduli terhadap permasalahan sosial di lingkungan sekitar, (6) berpartisipasi dalam masalah bersama dengan cara terbuka, (7) sopan dan berperilaku baik.

Langkah 2. Memilih masalah untuk bahan kajian kelas

Di dalam langkah kedua ada beberapa civic disposition yang muncul antara lain, (1) tanggung jawab terhadap tugas yang telah diterima baik dari dosen maupun dari teman sebaya, (2) penghargaan terhadap harkat dan martabat manusia, (3) mahasiswa memiliki kepedulian sosial dengan indikasi mampu menjabarkan permasalahan sosial yang ada dalam masyarakat, (4) memiliki kemampuan berpikir kritis dengan ikut berpendapat terkait permasalahan sosial apa yang akan dijadikan bahan kajian kelas, (5) menghargai pendapat teman sebaya ketika berdiskusi, (6) bernegoisasi dan berkompromi untuk memilih permasalahan sosial yang akan dijadikan bahan kajian kelas, (7) mempunyai kesopanan dan berperilaku baik.

Langkah 3. Mengumpulkan Informasi 
JURNAL MORAL KEMASYARAKATAN - VOL.2, NO.2, DESEMBER 2017 PEMBINAAN CIVIC DISPOSITION MELALUI MODEL PEMBELAJARAN PROJECT CITIZEN

Di dalam langkah ketiga ada beberapa civic disposition yang muncul antara lain, (1) tanggung jawab terhadap tugasnya yaitu mencari sumber yang dapat digunakan untuk mendukung tugas kelompoknya, (2) disiplin dengan pembagian waktu dan pembagian tugas kelompok, (3) penghargaan terhadap harkat dan martabat manusia, (4) memiliki kepedulian sebagai warga negara, (5) saat mengumpulkan informasi baik di perpustakaan maupun bertemu dengan kepala instansi menjunjung tinggi kesopanan dan berperilaku baik, (6) mengindahkan aturan main, (7) berpikir kritis dalam mengumpulkan informasi, (8) kemauan untuk mendengar, (9) bernegoisasi dan berkompromi dengan orang lain saat mengumpulkan informasi, (10) ikut berpartisipasi aktif dalam masalah bersama dengan cara yang terbuka, (11) mengembangkan kepercayaan pada diri sendiri.

Langkah 4. Mengembangkan Portofolio Kelas

Di dalam langkah keempat ada beberapa civic disposition yang muncul antara lain, (1) memiliki tanggung jawab menyelesaikan penelitian di lapangan, (2) tanggung jawab menyelesaikan portofolio kelompok, (3) disiplin kerja dan waktu, (4) penghargaan terhadap harkat dan martabat manusia, (5) kesopanan antar teman sebaya, (6) mengindahkan aturan main, (7) berfikir kritis dalam pembuatan portofolio kelompok, (8) kemauan mendengarkan saran dari teman kelompok, (9) bernegoisasi dan berkompromi dalam menyatukan berbagai macam pemikiran dari anggota kelompok, (9) menghormati hak orang lain, (10) ikut berpartisipasi aktif dalam masalah bersama dengan cara yang terbuka, (11) mengembangkan kepercayaan pada diri sendiri.

\section{Langkah 5. Menyajikan Portofolio}

Di dalam langkah kelima ada beberapa civic disposition yang muncul antara lain, (1) memiliki tanggung jawab untuk menyajikan portofolio, (2) disiplin diri dan kelompok, (3) penghargaan terhadap harkat dan martabat manusia, (4) kepeduliaan sebagai warga negara, (5) kesopanan dalam mempresentasikan portofolio kelompok, (6) mengindahkan aturan main dalam presentasi, (7) berpikir kritis, (8) kemauan untuk mendengar pendapat dari orang lain, (9) bernegoisasi dan berkompromi, (10) menghormati hak orang lain, (11) memajukan kebaikan umum dengan cara menyampaikan hasil kerja kelompok tentang jawaban dari permasalahan sosial yang diangkat menjadi bahan kajian kelas, (12) ikut berpartisipasi aktif dalam masalah 
JURNAL MORAL KEMASYARAKATAN - VOL.2, NO.2, DESEMBER 2017 PEMBINAAN CIVIC DISPOSITION MELALUI MODEL PEMBELAJARAN PROJECT CITIZEN

bersama dengan cara yang terbuka, (13) mengembangkan kepercayaan pada diri sendiri dan kelompok.

Langkah 6. Merefleksi Pengalaman Belajar

Di dalam langkah keenam ada beberapa civic disposition yang muncul antara lain, (1) memiliki tanggung jawab telah menyelesaikan presentasi portofolio, (2) kesopanan, (3) kemauan mendengarkan, (4) memajukan kebaikan umum, (5) mengembangkan kepercayaan diri, (6) terbuka dan toleran.

\section{Pembahasan}

\section{Pembinaan Civic Disposition melalui Model Pembelajaran Project Citizen dalam mata kuliah Pendidikan Kewarganegaraan 2 untuk menumbuhkan nilai moral mahasiswa.}

Civic disposition atau karakter kewarganegaraan merupakan komponen ketiga dari civic competence (kompetensi warga negara) yang berkaitan dengan sikap, watak, karakter dari warga negara. Karakter kewarganegaraan ini lebih mengarah pada karakter privat dan karakter publik warga negara. Menurut Winataputra dan Budimansyah (2012: 205) menyebutkan bahwa karakter privat seperti tanggung jawab moral, disiplin diri, dan penghargaan terhadap harkat dan martabat manusia dari setiap individu. Sedangkan karakter publik seperti kepedulian sebagai warga negara, kesopanan, mengindahkan aturan main dan berkompromi.

Kata character berasal dari bahasa Yunani charassein, yang berarti to engrave (melukis, menggambar), seperti orang yang melukis kertas, memahat batu atau metal. Berakar dari pengertian yang seperti itu, character kemudian diartikan sebagai tanda atau ciri yang khusus, dan karenanya melahirkan sutu pandangan bahwa karakter adalah pola perilaku yang bersifat individual, keadaan moral seseorang. Setelah melewati tahap anak-anak, seseorang memiliki karakter, cara yang dapat diramalkan bahwa karakter seseorang berkaitan dengan perilaku yang ada di sekitar dirinya (Kevin Ryan, 1999:5). Karakter yang baik berkaitan dengan mengetahui yang baik (knowing the good), mencintai yang baik (loving the good), dan melakukan yang baik (acting the good). Ketiga ideal ini satu sama lain sangat berkaitan. Seseorang lahir dalam keadaan bodoh, dorongan-dorongan primitif yang ada dalam dirinya kemungkinan dapat memerintahkan atau menguasai akal sehatnya. Maka, efek yang mengiringi pola pengasuhan dan pendidikan 
JURNAL MORAL KEMASYARAKATAN - VOL.2, NO.2, DESEMBER 2017 PEMBINAAN CIVIC DISPOSITION MELALUI MODEL PEMBELAJARAN PROJECT CITIZEN

seseorang akan dapat mengarahkan kecenderungan, perasaan, dan nafsu besar menjadi beriringan secara harmoni atas bimbingan akal dan juga ajaran agama (Sudrajat, 2011).

Permasalahan karakter tidak hanya dihadapi pada satu perguruan tinggi maupun sekolah, namun juga dihadapi oleh semua warga negara Indonesia. Sebagaimana diketahui di berbagai media massa, media cetak, maupun di internet banyak kasus yang menyeret para elite politik, berita pembunuhan, berita pemerkosaan, berita begal dan masih banyak terkait dengan penyakit sosial. Hal tersebut menandakan bahwa permasalahan karakter di Indonesia sudah akut untuk segera diatasi. Menurut Samani dan Hariyanto (2013: 2) menyebutkan bahwa di Indonesia pendidikan karakter saat ini memang dirasakan mendesak untuk dilakukan secara maksimal. Pendidikan Karakter di Indonesia dirasakan amat perlu pengembangannya bila mengingat makin meningkatnya tawuran antar pelajar, serta bentuk-bentuk kenakalan remaja, pemerasan/kekerasan termasuk bullying. Sedangkan yang paling mengejutkan adalah upaya untuk membangun kejujuran pada siswa melalui kantin kejujuran gagal dikarenakan bangkrut, dan semakin banyaknya penggunan dan pengedar narkoba di Indonesia.

Manullang (2013) menyebutkan bahwa krisis bangsa adalah krisis karakter baik dalam perspektif nomotesis maupun ideografis. Persektif nomotesis mengisyaratkan Pancasila sebagai sumber karakter NKRI. Perspektif nomotetis harus kuat karena sangat berpengaruh pada sikap, polapikir, komitmen dan kompetensi. Perspektif ideografis mengacu pada kemampuan produktif dan kreatif secara individual. Interaksi nomotesis dan ideografis terintegrasi dalam sikap positif, polapikir esensial, komitmen normatif dan kompetensi abilitas. Apabila karakter ini belum berkembang maka acuan perilaku baik atau kurang baik menjadi kurang jelas. Akibatnya, semua kelompok atau individu membuat acuan masing-masing. Kondisi ini rentan bermasalah, ada benturan, gesekan bahkan dimungkinkan sampai pada konflik horisontal, sebab semua kelompok mengklaim diri sebagai komunitas yang benar.

Hal di atas menandakan bahwa peran pendidikan belum seutuhnya berhasil karena output dari sekolah maupun perguruan tinggi belum optimal sehingga timbul pertanyaan mengapa pendidikan di Indonesia belum mampu mengubah perilaku bangsa Indonesia, dan mengapa banyak orang pintar di Indonesia namun belum bisa membangun karakter bangsa Indonesia. Samani dan Hariyanto (2013: 9) mengungkapkan semakin mendesaknya implementasi pendidikan karakter di Indonesia. Pusat Kurikulum Badan Penelitian dan Pengembangan 
JURNAL MORAL KEMASYARAKATAN - VOL.2, NO.2, DESEMBER 2017 PEMBINAAN CIVIC DISPOSITION MELALUI MODEL PEMBELAJARAN PROJECT CITIZEN DALAM MATA KULIAH PKn 2 UNTUK MENUMBUHKAN NILAI MORAL MAHASISWA

Kementerian Pendidikan Nasional dalam publikasinya berjudul Pedoman Pelaksanaan Pendidikan Karakter menyatakan bahwa pendidikan karakter pada dasarnya bertujuan membentuk bangsa yang tanggung, kompetitif, berakhlak mulia, bermoral, bertoleransi, bergotong royong, berjiwa patriotik, berkembang dinamis, berorientasi ilmu pengetahuan dan teknologi yang semuanya dijiwai oleh iman dan takwa kepada Tuhan Yang Maha Esa berdasarkan Pancasila.

Zuchdi (2008:6-8) dalam Winarni (2013) mengemukakan supaya pendidikan moral/nilai (pendidikan karakter) tidak bersifat indoktrinatif, mahasiswa perlu didorong untuk dapat menemukan alasan-alasan yang mendasari keputusan moral. Tujuannya untuk mengembangkan kemampuan mengontrol tindakan yang diperlukan agar seseorang dapat benar-benar memahami keputusan moral yang diambilnya, dapat mengidentifikasi alasan yang baik yang harus diterima dan alasan yang tidak baik yang harus ditolak atau diubah. Pada akhirnya mahasiswa harus mampu merumuskan perubahan yang perlu dilakukan. Pembelajaran mestinya menciptakan setting sosial yang memungkinkan implementasi pengetahuan yang diperoleh untuk memecahkan masalah yang ada dalam masyarakat. Selanjutnya, pendidikan moral/nilai hendaknya difokuskan pada kaitan antara pemikiran moral (moral thinking) dan tindakan bermoral (moral action). Konsep moralitas perlu diintegrsasikan dengan pengalaman dalam kehidupan sosial. Pemikiran moral dapat dikembangkan antara lain dengan dilema moral yang menuntut kemampuan untuk mengambil keputusan dalam situasi yang sangat dilematis. Tindakan moral yang selaras dengan pemikiran moral hanya mungkin dicapai melalui pencerdasan emosional dan spiritual serta pembiasaan.

Frankena (Adisusilo, 2012:128) yang dikutip oleh Setiawan (2013) mengemukakan bahwa tujuan pendidikan moral mencakup: (1) membantu peserta didik untuk dapat mengembangkan tingkah-laku yang secara moral baik dan benar, (2) membantu peserta didik untuk dapat meningkatkan kemampuan refleksi secara otonom, (3) membantu peserta didik untuk menginternalisasikan nilai-nilai moral, norma-norma dalam menghadapi kehidupan konkretnya, (4) membantu peserta didik untuk mengadopsi prinsip-prinsip universal, nilai-nilai kehidupan sebagai pijakan untuk pertimbangan moral dalam menentukan suatu keputusan, dan (5) membantu peserta didik untuk mampu membuat keputusan yang benar, bermoral, dan bijaksana. Untuk menanamkan karakter-karakter serta moral pada mahasiswa diperlukan pendekatan yang 
JURNAL MORAL KEMASYARAKATAN - VOL.2, NO.2, DESEMBER 2017 PEMBINAAN CIVIC DISPOSITION MELALUI MODEL PEMBELAJARAN PROJECT CITIZEN

cocok, dikarenakan mahasiswa sudah menjadi orang dewasa yang cara belajarnya berbeda pada siswa SMP dan SMA. Menurut Srinivasan (1997: 35-68) dalam Basleman dan Mappa (2011:2327) mengungkapkan ada tiga pendekatan orang dewasa terhadap belajar sebagai berikut:

a. Pendekatan yang berpusat pada masalah

Kurikulum yang berpusat pada masalah mengerahkan pada pengalaman belajar masalah yang dihadapi warga belajar dalam kehidupan sehari-hari untuk memperlihatkan kepada warga belajar bahwa pengetahuan yang diperoleh terkait erat dan gunanya dengan masalah yang dihadapi.

\section{b. Pendekatan Proyektif}

(1) Perencanaan kurikulum menjabarkan mata pelajaran dalam kurikulum yang kemudian dijadikan satuan pelajaran yang kecil, (2) Ilustrasi mengandung rangsangan dan kata kunci yang berkaitan dengan masalah atau konsep, (3) Format lepas memungkinkan warga belajar melengkapi buku bacaan awal dengan menambah selembar atau satu-satuan bagian tertentu.

c. Pendekatan Aktualisasi Diri

(1) Proses berpusat pada warga belajar dan proses digerakkan oleh warga belajar, (2) Belajar dengan teman sejawat (3) Belajar memudahkan terciptanya konsep diri yang positif.

Berdasarkan pendapat di atas dapat diketahui bahwa pendekatan belajar pada orang dewasa sangat berbeda dengan belajar pada usia remaja. Pada orang dewasa proses pembelajaran berpusat penuh pada warga belajar sehingga peran guru atau dosen hanya sebagai fasilitator, dan pembelajaran akan tercipta kondisi aktif. Selain mengenali pendekatan belajar orang dewasa, perlu juga dipahami faktor-faktor yang mempengaruhi pembelajaran orang dewasa, sebagaimana yang diungkapkan oleh Basleman dan Mappa (2011: 29-45) faktor yang mempengaruhi proses pembelajaran pada orang dewasa antara lain: Faktor Fisiologis yang terdiri dari (a) pendengaran, (b) penglihatan, Faktor Psikologis yang terdiri dari (a) kecerdasan/bakat, (b) motivasi, (c) perhatian, (d) berpikir, (e) ingatan/lupa, (f) belajar lanjut, (g) reviu/resitasi, Faktor Lingkungan Belajar yang terdiri dari (a) lingkungan belajar dalam kampus/tempat belajar, (b) lingkungan belajar di luar kampus/tempat belajar, Sistem Penyajian yang terdiri dari (a) kurikulum, (b) bahan belajar, (c) metode penyajian. 
JURNAL MORAL KEMASYARAKATAN - VOL.2, NO.2, DESEMBER 2017 PEMBINAAN CIVIC DISPOSITION MELALUI MODEL PEMBELAJARAN PROJECT CITIZEN DALAM MATA KULIAH PKn 2 UNTUK MENUMBUHKAN NILAI MORAL MAHASISWA

Model pembelajaran Project Citizen merupakan sebuah model pembelajaran yang diadopsi dari Amerika, kemudian diterapkan di Indonesia dengan menyesuaikan keadaan pendidikan di Indonesia. Project citizen dapat diartikan sebagai wujud benda fisik, sebagai suatu proses sosial pedagogis, maupun sebagai adjective. Sebagai wujud benda fisik, project citizen adalah sebuah kumpulan pekerjaan siswa yang bermanfaat, terintegrasi yang diseleksi dan disimpan dalam suatu bundle (Budimansyah, 2002: 1). Model pembelajaran ini memerlukan kerja keras yang tidak sedikit, karena diperlukan kerja sama yang baik dalam sebuah tim. Terdapat beberapa sifat model pembelajaran Project Citizen yang dikemukakan oleh Djahiri (2000: 6-7) antara lain: (a) aktif dan meaningfull, (b) inquiry learning atau problem solving, (c) integrated learning, (d) cooperative learning, (e) student based, (f) factual based, (g) democratic. Dari ketujuh sifat pembelajaran Project Citizen dapat diketahui bahwa banyak dampak positif yang akan diperoleh ketika model pembelajaran ini secara maksimal diteraapkan dalam sebuah proses pembelajaran.

Selain dituntut adanya kerjasama dalam sebuah tim, model pembelajaran ini juga memerlukan adanya partisipasi aktif dari semua peserta didik. Hal ini senada diungkapkan oleh Budimansyah (2002: 8-12) yang dikutip Haryati dan Rochman (2012) bahwa prinsip dasar model pembelajaran Project Citizen adalah prinsip belajar siswa aktif, kelompok belajar kooperatif, pembelajaran partisipatorik. Project Citizen sebagai sebuah model pembelajaran tentunya mempunyai langkah-langkah bagaimana model pembelajaran ini dapat diterapkan secara tepat di kelas, langkah-langkah model pembelajaran project citizen sebagai berikut: (a) Mengidentifikasi masalah kebijakan publik dalam masyarakat, (b) Memilih suatu masalah untuk dikaji oleh kelas, (c) Mengumpulkan informasi yang terkait pada masalah, (d) Mengembangkan project citizen kelas, (e) Menyajikan project citizen, (f) Melakukan refleksi pengalaman belajar.

Generasi muda sebagai agen of change mempunyai makna bahwa pembangunan dan eksistensi suatu negara ada pada generasi muda yang akan melanjutkan tongkat estafet pembangunan bangsa dan negara. Oleh karena itu generasi muda perlu pembinaan dan pengembangan nilai moral agar tidak salah mengambil tindakan yang pada akhirnya akan merugikan kehidupan bahkan masa depannya. Menurut Roelan dalam Affandi (1996: 32) menyatakan pembangunan tidak hanya menyangkut pembangunan ekonomi dan sosial, tetapi menyangkut kelanjutan pembangunan negara (state building) dan juga berkaitan dengan kelestarian pembangunan watak bangsa (nation and character building). 
JURNAL MORAL KEMASYARAKATAN - VOL.2, NO.2, DESEMBER 2017 PEMBINAAN CIVIC DISPOSITION MELALUI MODEL PEMBELAJARAN PROJECT CITIZEN DALAM MATA KULIAH PKn 2 UNTUK MENUMBUHKAN NILAI MORAL MAHASISWA

Hal di atas memberikan pengertian bahwa pembangunan tidak hanya meliputi pembangunan infratruktur saja, namun juga pembangunan watak watak bangsa yang menjadi identitas bangsa. Hal tersebut menjadi penting untuk mempertahankan eksistensi bangsa yang pada dasarnya berdasarkan nilai-nilai Pancasila dan ketimuran yang harus dijaga dan dibina, mengingat arus globalisasi yang menmbuat batas-batas negara menjadi kabur. Menurut Tilaar dalam Affandi (1996: 34) dalam pendidikan terdapat pendekatan ekosferis yang mengimplikasikan dua hal, yakni Pertama, kepemudaan dan kehidupan orang dewasa serta anak merupakan totalitas. Kedua, apa yang menggolongkan generasi tua pun generasi muda dan anakanak semuanya berbeda dalam status yang sama dalam hal sedang menghadapi atau berbeda dalam suatu wawasan kehidupan.

Melihat dari tujuan sistem pendidikan di Indonesia memang lebih menitik beratkan pada pembentukan karakter generasi muda melalui pendidikan terutama pada Pendidikan Kewarganegaraan yang memang mempunyai misi sejalan dengan tujuan pendidikan nasional. Namun ada beberapa masalah dalam implementasi PKn di Indonesia menurut Budimansyah (2010: 142) antara lain: (1) masukan instrumental (instrumental input) terutama yang berkaitan dengan kualitas guru/dosen serta keterbatasan fasilitas dan sumber belajar, (2) masukan lingkungan (environmental input) terutama yang berkaitan dengan kondisi dan situasi kehidupan pilitik negara yang melenceng dari kehidupan demokrasi yang dicita-citakan.

Oleh karena itu selama ini pelaksanaan PKn menunjukkan salah arah, sehingga misinya pun tidak akan tercapai dengan maksimal, menurut Budimansyah (2010: 142-143) beberapa indikasi salah arah tersebut antara lain: (1) proses pembelajaran dan penilaian dalam PKn lebih menekankan pada dampak instruksional (instructional effects) yang terbatas pada penguasaan materi (content mastery) atau dengan kata lain hanya menekankan pada dimensi kognitifnya saja, (2) pengelolaan kelas belum mampu menyiptakan suasana kondusif dan produktif untuk memberikan pengalaman belajar kepasa siswa/mahasiswa melalui perlibatannya secara produktif dan interaktif baik dalam proses pembelajaran di kelas maupun di luar kelas (intra dan eksta kurikuler) sehingga berakibat pada miskinnya pengalaman belajar yang bermakna untuk mengembangkan kehidupan dan perilaku siswa/mahasiswa, (3) pelaksanaan kegiatan ekstra kurikuler sebagai wahana sosio-pedagogis untuk mendapatkan hands on experience juga belum memberikan kontribusi yang signifikan untuk menyeimbangkan antara penguasaan teori dan 
praktek pembiasaan perilaku dan keterampilan dalam berkehidupan yang demokratis dan sadar hukum.

Berbagai indikasi salah arah yang telah dikemukakan di atas, tentunya harus segera dicarikan solusi untuk menjawab berbagai persoalan di atas. Sehingga misi PKn untuk mengembangkan dan membina karakter generasi muda memperoleh titik terang dan dapat maksimal untuk mencapai misi tersebut. Budimansyah (2010: 144-145) mengemukakan sebuah gagasan untuk menjawab indikasi salah arah di atas dengan mereposisi PKn ke dalam tiga peran. (1) PKn sebagai program kurikuler di lembaga pendidikan formal (sekolah/perguruan tinggi) maupun di lembaga nonformal (luar sekolah), yang berperan sebagai wahana pemuliaan dan pemberdayaan anak dan pemuda sesuai dengan potensinya agar menjadi warga negara yang cerdas dan baik, (2) PKn sebagai gerakan sosio-kultural kewarganegaraan yang berperan sebagai wahana aktualisasi diri warga negara baik secara perorangan maupun kelompok sesauai dengan hak, kewajiban, dan konteks sosial budayanta, melalui partisipasi aktif secara cerdas dan bertanggung jawab, (3) PKn sebagai program pendidikan politik kebangsaan bagi para penyelenggara negara, anggota dan pemimpin organisasi yang dikemas dalam berbagai bentuk pembinaan pengetahuan kewarganegaraan (civic knowledge), kecakapan kewarganegaraan (civic skills), dan watak kewarganegaraan (civic disposition) yang mengacu pada prinsip konseptualpedagogis untuk mengembangkan daya nalar, bukan wahana indoktrinasi politik, dan sebagai suatu proses pencerdasan.

\section{PENUTUP}

\section{Simpulan}

Pembinaan civic disposition yang dibelajarkan pada mahasiswa melalui model pembelajaran project citizen dalam mata kuliah Pendidikan Kewarganegaraan 2 memiliki peranan penting dalam menumbuhkan nilai moral pada mahasiswa. Upaya ini tentunya untuk memperkuat mata kuliah Pendidikan Kewarganegaraan 2 agar yang diajarkan tidak hanya terfokus kepada pengetahuan saja, tetapi juga menyentuh kepada aspek karakter yang bisa menumbuhkan nilai moral pada mahasiswa. Beberapa civic disposition yang muncul dalam pembelajaran PKn 2 dengan model pembelajaran project citizen antara lain: tanggung jawab, disipilin, penghargaan terhadap harkat dan martabat manusia, kepedulian, kesopanan, berpikir 
JURNAL MORAL KEMASYARAKATAN - VOL.2, NO.2, DESEMBER 2017 PEMBINAAN CIVIC DISPOSITION MELALUI MODEL PEMBELAJARAN PROJECT CITIZEN DALAM MATA KULIAH PKn 2 UNTUK MENUMBUHKAN NILAI MORAL MAHASISWA

kritis, kemauan mendengar, bernegosiasi dan berkompetensi, memajukan kebaikan umum, berpartisipasi dalam masalah bersama dengan cara yang terbuka, mengembangkan kepercayaan diri.

\section{Rekomendasi}

Berdasarkan hasil temuan dan pembahasan di atas, maka penulis merumuskan beberapa rekomendasi sebagai berikut: Pembelajaran Pendidikan Kewarganegaraan 2 dibiasakan dengan menggunakan model pembelajaran yang bervariasi, tentunya memperhatikan aspek pengetahuan, keterampilan, dan karakter agar tujuan PKn untuk menjadikan warga negara yang baik dan cerdas (to be smart and good citizen) dapat tercapai dengan baik. Model pembelajaran project citizen mampu mengembangkan nilai moral mahasiswa dengan melakukan pembinaan pada civic disposition di setiap langkah-langkah pembelajaran. Oleh karena itu ke depannya diperlukan pengembangan model tersebut agar lebih bervariasi. Peneliti menghimbau kepada pemerhati (dosen, guru, peneliti, pemerintah, masyarakat) untuk mendukung keilmuan PKn.

\section{DAFTAR RUJUKAN}

Affandi, I. (1996). Keploporan Organisasi Kemasyarakatan Pemuda dalam Pendidikan Politik. (Disertasi). Bandung: SPs UPI Bandung.

Basleman, A dan Mappa, S. (2011). Teori Belajar. Bandung: PT. Remaja Rosdakarya.

Budimansyah, D dan Winataputra. (2012). Pendidikan Kewarganegaraan dalam Perspektif Internasional (Konteks, Teori, dan Profil Pembelajaran). Bandung: Widya Aksara Press.

Budimansyah, D. (2002). Model Pembelajaran dan Penilaian Berbasis Portopolio. Bandung: Penerbit PT Genesindo.

Budimansyah, D. (2010). Tantangan globalisasi terhadap pembinaan wawasan kebangsaan dan cinta tanah air di sekolah. Jurnal Penelitian Pendidikan. (Online), Vol 11, No. 1, April 2010.

Budimansyah, D. (2012). Perancangan Pembelajaran Berbasis Karakter Seri Pembinaan Profesionalisme Guru. Bandung: Widya Aksara Press.

Djahiri, A. Kosasih. (2000). Memahami Makna dan Isi Pesan Pembelajaran dan Portofolio Learning and Evaluation Based. Bandung: PPs UPI.

Eleanora, N, F. (2011). Bahaya Penyalahgunaan Narkoba Serta Usaha Pencegahan Dan Penanggulangannya (Suatu Tinjauan Teoritis). Jurnal Hukum. (Online), Vol XXV, No 1, April 2011.

Haryati, T dan Rochman, N. (2012). Peningkatan Kualitas Pembelajaran Pendidikan Kewarganegaraan Melalui Praktik Belajar Kewarganegaraan (Project Citizen). Jurnal Ilmiah CIVIS. (Online), Vol. II, No. 2, Juli 2012. 
Kenakalan Remaja. [Online]. Tersedia di http://health.liputan6.com/read/688614/berbagaiperilaku-kenakalan-remaja-yang-mengkhawatirkan?p=3. Diakses 12 November 2017.

Manullang, B. 2013. Grand Desain Pendidikan Karakter Generasi Emas 2045. Jurnal Pendidikan Karakter. (Online), No. 1, Tahun III, Februari 2013.

Remaja di Indonesia Rentan Berperilaku Tidak Sehat. [Online]. Tersedia di http://beritasore.com/2010/07/05/separuh-dari-63-juta-jiwa-remaja-di-indonesia-rentanberprilaku-tidak-sehat/. Diakses 12 November 2017.

Samani, M dan Hariyanto. (2013). Pendidikan Karakter. Bandung: PT. Remaja Rosdakarya Offset.

Setiawan, D. (2013). Peran Pendidikan Karakter Dalam Mengembangkan Kecerdasan Moral. Jurnal Pendidikan Karakter. (Online), No. 1, Tahun III, Februari 2013.

Sudrajat, A. (2011). Mengapa Pendidikan Karakter?. Jurnal Pendidikan Karakter. (Online), No. 1, Tahun I, Oktober 2011.

Wening, S. (2012). Pembentukan Karakter Bangsa Melalui Pendidikan Nilai. Jurnal Pendidikan Karakter. (Online), No. 1, Tahun II, Februari 2012.

Winarni, S. (2013). Integrasi Pendidikan Karakter Dalam Perkuliahan. Jurnal Pendidikan Karakter. (Online), No. 1, Tahun III, Februari 2013.

Winarno. (2013). Pembelajaran Pendidikan Kewarganegaraan (Isi, Strategi, dan Penilaian. Jakarta: Bumi Aksara.

Winataputra, U, S. (2001). Jatidiri Pendidikan Kewarganegaraan sebagai Wahana Pendidikan Demokrasi. (Disertasi). Sekolah Pascasarjana, Universitas Pendidikan Indonesia, Bandung. 